\title{
Impression Management in the Marketing Context
}

\author{
Rudin Beka, PhD Candidate \\ Luigji Gurakuqi University, Albania \\ rudinbeka@yahoo.it
}

\section{Doi:10.5901/mjss.2013.v4n11p463}

\begin{abstract}
The main idea of this paper is to analyze previous studies that have been done so far regarding impression management and its implication on marketing impressions. Since some of the studies suggest that marketing ventures involve activities that parallel those commonly found in impression management, perhaps now is time to explore impression management in the context of marketing. Design/Methodology/Approach - The research is based mainly on reviewing and analyzing previous studies in different journals from the marketing and psychology field.Findings - It was interesting to figure out that there was paid relatively little attention to marketing impression and especially in the use of impression in the integrated marketing communications area.Practical implications - The findings could have an impact on retail and service business, in guiding marketers how should they approach and impress better customers. Originality/value - Reviewing the existing literature and researches about impression management the author states that there is not much done. The previous authors have mainly focused their researches on the management level and especially in that of individual or organization stage, but not on the use of impression management in the marketing communication process.
\end{abstract}

Keywords: Impression marketing, impression management, integrated marketing communications

\section{Impression Management}

The general idea of impression management is based on creating desired image through specific behaviors, on individual or organizational bases. Individuals try to base their impressions on building images and on the other hand organizations are focused on a more complex structure, that of building reputations. Impression management describes efforts by an actor to create, maintain, protect, or otherwise alter an image held by a target audience (Bozeman \& Kacmar, 1997). To accomplish this goal, actors use a variety of tactics - specific behaviors (e.g., compliment the target) designed to create a desired image (Jones \& Pittman, 1982; Tedeschi \& Melburg,1984).

Most of the research on impression management deals with how individuals can manage the impressions they make by monitoring their own behavior, varying their dress, what they say and do in a placement interview, taking part in team projects, or the timing of their arrival at or departure from work (Grunig 1993). Impression management cannot be used only at the individual level, but also in a corporate level. Different studies suggest that organizations can use impression management tactics to create an organizational image in the eyes of a variety of constituencies (Bolino, 2008). As an area of scholarship, corporate reputation is a relative newcomer, attracting attention from scholars in advertising, marketing, psychology, organizational behavior, strategy, and communications. (S. Highhouse, M. Brooks, G. Gregarus 2009). Continuing Gregarus analyses, images that external audiences hold about companies when maintained over time and interactions develop into a general impression, reflecting the respect or admiration with which an organization is held.

Moreover, Harris and Spiro (1981) defined impression management as "an influence attempt based on the manipulation by a salesperson of the impressions he creates in order to achieve a predetermined favorable response on the part of the indented message receiver.

To be sure, there are numerous ways in which to define impression management, yet at the centre of any of these is the recognition that people's comprehension of a phenomenon can be directed by others and their attempts to frame one's perception. (Grunig 1993)

Impression management behavior can be both assertive and defensive in nature (Tedeschi and Norman 1985). Assertive impression management is used to form desired images in the minds of a target audience.

Defensive impression management, on the other hand, seeks to repair or protect an intended image that is threatened by and undesirable outcome. 
Grunig (1993) argues that image disguises the more precise concepts of perception, cognition, attitude, and schema-concepts that identify symbolic objectives for public relations. Over the long term, however, organizations must evaluate the contribution of these objectives to the behavioral relationships with publics if they are to help organizations achieve their goals and missions.

As mentioned also above, one of the most critical parts of impression management is how to build a positive image. First it has to be reviewed that image has been used as a synonym for such concepts as message, reputation, perception, cognition, attitude, credibility, belief, communication, or relationship. (Grunig 1993)

As one author sad:

Of course, image is not a bad word, and practitioners should not have their mouths washed out with soap every time they use it. In the communication process, the goal of the sender-communicator is to convey a message to the receiveraudience in a form as identical as possible to what is in the mind of that sender. What the receiver gets after the message is encoded, sent, and decoded, however, is really an image or reproduction of the thoughts or feelings of the sender, not the thoughts or feelings themselves

(Haberman \& Dolphin, 1988.

The concept above suggests that image refers to a number of symbolic relationships that are important complements to the building of behavioral relationships between an organization and its publics. (Grunig 1993) However, most organizational members presumably want their company to be respected and admired. Images that external audiences hold about companies (e.g., as producers of goods and services, as employers, as corporate citizens) when maintained over time and interactions develop into a general impression, reflecting the respect or admiration with which an organization is held. (S. Highhouse, M. Brooks, G. Gregaruss, 2009) From a marketing perspective, a positive image assists a channel member in establishing a favorable market position, in pre-selling potential partners to support product marketing, in redefining its identity after a merger, or in offsetting the negative consequences of a crisis situation. (Young, Gardner and Gilbert 2001)

\section{Impression Marketing}

Among some of the more inventive ways in which the activity of marketing, in general or in part, has been depicted in recent years are descriptions of marketing strategy as a kind of "warfare", the marketing of services as "theater", consumer transactions as "performances", consumption as "experience" and a host of other such novel representations (Raymond P. Fisk, Stephen J. Grove 1996).

Based on the observations posited above, a great deal of marketing activity can be classified as impression management. The creativity and persuasion embodied by impression management are characteristics which are often found across vendors' pursuit of the elusive customer. (Raymond P. Fisk, Stephen J. Grove, 1996)

The main idea in marketing impression is how to understand the dynamics involved in influencing consumer demand and actually there are different activities of the marketing mix that are merged with impression management. We have the case of the visual aspects of a corporation's marketing materials, which are receiving increasing attention in marketing today and within this area the typeface design is one of the most important ones. The type face affects perceptions of advertised brands, influences the readability and memorability of advertisements and last but not least it creates strategically important impressions e.g., general positive image to more specific impressions of innovativeness, change, power, or warmth. (: P. Henderson, J. Giese, J. Cote )

Moreover, the distribution channel and personal selling are the other two instruments of marketing mix which can be described as part of impression management. In the context of personal selling, an understanding of impression management may enable sales personnel to "design their communications to impress prospects or clients" (King and Booze, 1986, p. 52). However, one of the most important aspects today in the marketing area is the recognition that consumers, in their decision making process, evaluate not only the product itself but also the intangible features of the product being offered. Service, warranty, packaging, advertising, financing, pleasantries, image, the place where product is distributed, more specifically the atmosphere of the place, are some of the indicators why customer purchase the product. (Ph. Kotler 1973) Kotler actually was one of the first researchers which studied the effects that atmospheric and architecture had on creating specific emotional impulse on the buyer.

Architecture reflects the brand in the consistency of its design and visual appearance. For retailers these distinctions are particularly important, since retail identity is communicated in and experienced through their stores, both internally and externally. (Ph. Kotler 1973) From the 1980s, fashion designers, including Armani, Comme des 
Garcons and Gucci, hired architects to distinguish their brand, buildings, megastores and epicenters to extend their prestige. Such unusually and extravagantly designed stores served as three-dimensional advertisements to promote the fashion brand name. Interior design's ability to generate impressions of personality has not yet been formally established. (A. Kirby, A, Kent 2010). Within the environment there are different tools that are being used to get awareness and capture consumer attention. Visual, aural, olfactory, and tactile dimensions of service environments have been examined to assess their abilities to convey important information (Baker, 2002) and arouse emotions (Bitner, 1992) On the other hand, Turley and Milliman (2000) established five broad categories of atmospheric cues, including: external cues (e.g. architectural style and surrounding stores); general interior cues (e.g. flooring, lighting, color schemes, music, aisle width and ceiling composition); layout and design cues (e.g. space design and allocation, grouping, traffic flow, racks and cases); point of purchase and decoration displays (e.g. signs, cards, wall decorations, price displays); and human variables (e.g. employee characteristics, uniforms, crowding and privacy). Within these broad categories, a total of 57 specific cues were identified.

Furthermore, in an interesting study done by Ballantine, Jack and Parsons (2010), on two big retail shops, regarding the cues that impressed more or had the biggest impact on consumer behavior they figured out the relative importance of product display features, which accounted of $38 \%$ of all discussion.

\section{Integrated Marketing Communications}

During the past decade, the concept of IMC has received wide attention in the marketing literature (Duncan and Everett, 1993; McArthur and Griffin, 1997; Schultz and Kitchen, 2000a). There are different school of thoughts regarding the precise meaning and definition of IMC (integrated marketing communications) but one of the most well used is the one from Shimp (2010), which states that integrated marketing communications is a communications process that entails the planning, creation, integration and implementation of diverse forms of marcom (advertisement, sales, promotions, publicity releases, events, etc) with the aim of directly effecting the behavior of the target audience.

As seen from the definition of Shimp, there are many ways for a service business to communicate with customers. The location and atmosphere of a service delivery facility, corporate design features such as the consistent use of colors and graphic elements, the appearance and behavior of employees, the design of the website-all contribute to an impression to the customer's mind. (Lovelock and Wirtz 2011)

At this point some promising research questions emerge and might be used as basic for further analyses.

A. How effective are today integrated communication strategies in building positive images?

B. Should IMC focus only on delivering information or should they focus more on building brand reputations?

C. Does experience economy merged with impression management help the IMC to deliver a better and a more successful information campaign?

Study how impression marketing shapes the experience economy, which is seen today as a new marketing communication tool, is the main goal of the author. The impression has to be associated with experience or the so called the experience economy. Carbone (1998) warns companies against the myopic view that they are exclusively in the product and service business (commodity business), rather than taking a broader one which recognizes the value they create as a total consumer experience.

Actually Pine and Gilmore (1999) were the first to formally announce the arrival of the experience economy era, which requires a new philosophy of marketing that prioritizes the consumer experience of product brands. Central to their thesis is the notion that companies now market and sell much more than just products, because consumer experience has become the core element. (Shu- pei Tsai 2005). An interesting case to be taken here is the example of Apple stores, which offer an attractive environment consisting with a pleasant design and giving the possibility consumers to learn and try electronics within the store.

On the other hand the experience interaction is seen also as an integral part of marketing strategies, as is the case of Pepsi which now engages in marketing through live-show product placements, special events with impressive atmospheric impact and brand community activities that tighten emotional bonding and continuously innovated product quality . (Shu- pei Tsai 2005).

As a conclusion, the research might be further expanded on how impression marketing employed in experience economy, influence properly the flow of information in integrated marketing communications. 


\section{References}

A. Kirby, A, Kent, Architecture as brand: store design and brand identity, Journal of Product \& Brand Management, page 433, 2010

Baker, J., Grewal, D. and Parasuraman, A. (1994), "The influence of store environment on quality inferences and store image", Journal of the Academy of Marketing Science, Vol. 22, No. 4, page. 328-39.

Bellizzi, J.A., Crowley, A.E. and Hasty, R.W. (1983), "The effects of color in store design", Journal of Retailing, Vol. 59 No. 1, page. 2145.

Bitner, M.J. (1990), "Evaluating service encounters: the effects of physical surroundings and employee responses", Journal of Marketing, Vol. 54 No. 2, pp. 69-82.

Bozeman, D. P., \& Kacmar, K. M. 1997. A cybernetic model of impression management processes in organizations.Organizational Behavior and Human Decision Processes, 9-30

Carbone, L. P. Total customer experience drives value, Management Review, page 62, 1998

Ch. Lovelock, J. Wirtz, Service Marketing, Prentice Hall, page 162, 2011

Haberman, D. Z., \& Dolphin, H. A. . Public Relations: The Necessary Art. Ames, IA: IowaState University Press. 1988

Duncan, T.R. and Everett, "Client perceptions of integrated marketing communications", ]ournal of Advertising Research, Vol. 33 May/June, page 30-9,1993

E. Goffman, The presentation of self in everyday life, Penguin; New Ed edition, page 6, 1990

Highhouse, M. Brooks, G. Gregaruss, Impression Management Perspective on the Formation of Corporate Reputations, Journal of Management, page 1483, 2009

Mark C. Bolino, A Multi-Level Review of Impression Management Motives and Behaviors, Journal of Management, page 1081, 2008

McArthur, D.N. and Griffin, T, "A marketing management view of integrated marketing communications", ]ournal of Advertising Research, Vol. 37 No. 5, page 19-28, 1997

J. Grunig, Image and Substance:From Symbolic to Behavioral Relationships, Public Relations Review, page 128, 1993

Tarence A. Shimp, Advertising, Promotion and other aspects of Integrated Marketing Communications, South-Western Cengage Learning, 2010

Raymond P. Fisk, Stephen J. Grove, Applications of impression management and the drama metaphor in marketing:an introduction, European Journal of Marketing, page 9, 1996

R. King, M. Booze, Sales Training and Impression Management, Journal of Personal Selling \& Sales Management, page 52, 1996

S. Highhouse M. Brooks, G. Gregarus, An Organizational Impression Management

Perspective on the Formation of Corporate Reputations, Journal of Management, page 1482-1493, 2009

P. Henderson, J. Giese, J. Cote, Impression Management Using Typeface Design, Journal of Marketing Vol. 68, page 60, 2004

P. Fisk, Stephen J. Grove, Applications of impression management and the drama metaphor in marketing: an introduction, European Journal of Marketing, page 9, 1996

P. Ballantine, Jack and Parsons, Atmospheric cues and their effect on the hedonic retail experience, Journal of Retail \& Distribution Management Vol. 38 No. 8, page 645, 2010

P. Henderson, J. Giese, J. Cote, Impression Management Using Typeface Design, Journal of Marketing Vol. 68, page 60, 2004

Ph. Kotler, Atmospherics as a marketing tool, Journal of Retail, page 48, 1973

Tedeschi, James T. and Nancy Norman, "Social Power, Self- Presentation, and the Self, Impression Management Theory and Social Psychological Research, New York: Academic Press, page 293-322, 1985

Shu- pei Tsai, Integrated marketing as management of holistic consumer experience, Business Horizons 48, page 432, 2005

Schultz, D.E. and Kitchen, P.J., Global Communications: An Integrated Marketing Approach, NTC Business Books, Chicago, IL, 2000

Tedeschi, J. T., \& Melburg, V. Impression management and influence in the organization. In S. B. Bacharach \& E. J. Lawler (Eds.), Research in the sociology of organizations: page 31-58, 1984

Turley, L. and Milliman, R. "Atmospheric effects on shopping behavior: a review of the experimental evidence", Journal of Business Research, Vol. 49, page 194, 2000

J. Young, W. Garnder, F. Gilbert, Impression Marketing Techniques in Marketing Channels, Journal of Marketing, page 29-38, 2001

Jones, E. E., \& Pittman, T. S. Toward a general theory of strategic self-presentation. In J. Suls (Ed.), Psychological perspectives on the self: Hillsdale, NJ: Lawrence Erlbaum, page 231-262, 1982

U. Orth, F. Einrich, K. Malewitz, Servicescape interior design and consumers' personality impressions, Journal of Services Marketing, Volume $26 \cdot$ Number 3, page 194-203, 2012 